\title{
Dream Palaces of Law: Western Constructions of the Muslim Legal World ${ }^{\dagger}$
}

\author{
By HaIder Ala Hamoudi*
}

When I was first called by Professors Reimann and Mattei and given the honor of an opportunity to speak before you on the subject of "How the West Views the Rest," my immediate concern was definitional. To some extent, this revolved around the mysterious term "Rest." What could I say, in only a few minutes, about the entire non-Western world that would not either be wildly inaccurate in any number of contexts, or so general as to be effectively meaningless? I did not ponder the matter long. Having no hope of providing any useful insights on how the West might view the entire rest of the world, and condemned with insufficient knowledge on important parts of that world to even render an opinion on it, I decided to confine most of my remarks to that portion of the earth on which I have some knowledge, the Muslim world, with a particular but by no means exclusive focus on that one country in the Muslim world whose fate is, in these perilous times, deeply intertwined with American interests and influences, Iraq. I hope that this examination might shed some light, however meager,

$\dagger$ Remarks from The West and the Rest in Comparative Law, 2008 Annual Meeting of the American Society of Comparative Law, University of California, Hastings College of the Law (Oct. 2-4, 2008).

* Assistant Professor of Law, University of Pittsburgh School of Law. J.D., J.S.D. Columbia Law School. Professor Hamoudi's scholarship focuses on commercial law, Middle Eastern law, Islamic law, and the intersection of these various bodies of law and legal doctrines in the contemporary era. He has written for numerous law reviews, spoken at conferences sponsored by the MacMillan Center at Yale University, the American Association of Law Schools and the New York City Bar Association, and given interviews to various news organizations including the Pittsburgh Post-Gazette, the McNeil-Lehrer News Hour Online and the New York Law Journal. Professor Hamoudi is also the author of a blog on Islamic Law entitled Islamic Law in Our Times. 
on the broader question of the West and its constructions of the Rest.

But in addition to what might perhaps be common confusion concerning precisely who the "Rest" are, how does one go about determining the "West?" This is a particularly acute problem when one has chosen the focal point of the "Rest" that I have. The West, when it comes to the Muslim world, especially Iraq, is no monolith; there are divisions everywhere. Chasms separate France from the United States, England from Germany, conservatives from liberals, academics from journalists, faithful from nonbelievers, in their projections of the Muslim East. Our region of the world is, depending on which Western constituency you might be speaking to, a dark and violent place governed by a false religion and the traditions of an evil prophet, 1 a backwards and silly part of the world that cannot seem to come to terms with economic development and modernity, ${ }^{2}$ a tragic story of good people of ordinarily moderate beliefs whose religion has been hijacked by forces of extremism, ${ }^{3}$ or any number of permutations or

1. This seems to be a rather popular position among certain elements of America's religious right in particular. Rev. Rod Parsley, for example, of the World Harvest Church of Columbus, Ohio, whose endorsement of John McCain had been sought for some number of months, described the Prophet Muhammad as "the mouthpiece of a conspiracy of spiritual evil" and Islam as an "anti-Christ," the destruction of which was a reason for the founding of the United States. See Brian Ross, Avni Patel and Rehab Al-Buri, McCain Pastor: Islam is a 'Conspiracy of Spiritual Evil', ABC News, May 22, 2008, http://abcnews.go.com/Blotter/Story?id=4905624 \&page $=1$ (last visited March 20, 2009). A United States Lieutenant General expressed similar sentiments. Brian Knowlton, General Compares Militants to 'Satan': Comments on Islam Irk the White House, INTERNATIONAL HERALD TRIBUNE (October 20, 2003), available at http://www.iht.com/articles/2003/10/20/policy_ed3_.php.

2. This appears to be a prevailing sentiment within particular European circles. The late Pim Fortuyn, for example, referred to Islam as fostering a "backwards culture." Obituary: Pim Fortuyn, BBC NEWS (May 6, 2002), available at http://news.bbc.co.uk/2/hi/europe/1971462.stm.

3. This of course is the politically correct rendition of Islam and the Muslim world repeated by countless statesmen in Western democracies. See, e.g., George W. Bush, United States President, Address at the Islamic Center of Washington, D.C. (Sept. 17, 2001), available at http://www.usdoj.gov/crt/legalinfo/ bushremarks.php ("The face of terror is not the true faith of Islam. That's not what Islam is all about. Islam is peace. These terrorists don't represent peace. They represent evil and war. When we think of Islam we think of a faith that brings comfort to a billion people around the world. Billions of people find comfort and solace and peace. And that's made brothers and sisters out of every race - out of every race."); Sarkozy Lauds Islam at Louvre Ceremony with Saudi Prince, AFP (July 16, 2008) (quoting Sarkozy as indicating that 'Islam is progress, science, finesse, modernity, and that fanaticism in the name of Islam is a corruption of Islam.'); 
combinations of these.

Finally, I believed it important to avoid the perils of selfcongratulation. That is, I did not want to lead an exercise in scoffing at the ignorant hordes who did not know an Arab from a Muslim, a Turk from an Egyptian, a Shi'ite from a Sunni, and bemoan the fact that such hordes controlled our political and civic discourse, and how much better all would be if only we academics were heard. There is much that is wrong with our understandings of the Muslim Rest, as the story of Iraq I hope will demonstrate, that pervades every community, from the most learned to the least enlightened.

In fact, in many ways Western distortions of the Muslim East nearly always take the same form, irrespective of who in the West is doing the distorting. One common theme can be generally gleaned from any projections of the Muslim East in the West, in any Western country, among nearly every community, including, and perhaps especially, our own academic community. This is the perception of the near ubiquitous role of Islam and, more germane to my remarks, Islamic law, of a historic, medieval kind, in governing the legal order of Muslim states, including Iraq, in a manner that can be entirely distorting. In these brief remarks, I hope first to expose this bias, and then to provide at least rudimentary ideas on how law, both Islamic and secular, in the Muslim world might better be studied and understood, particularly by comparatists.

The general, conventional story of Iraq, told countless times in the media, is that Saddam Hussein, as an archsecularist, albeit a brutal one, was adept at holding back the rising waters of political Islam within his own nation, even as the movement's tentacles spread elsewhere across the broader Muslim world.4 As a result, women were liberated and educated in Saddamist Iraq, the "envy of women across the Middle East," 5 alcohol was available, and Islamic

Matthew Tempest, Blair Launches Fund to Improve Teaching of Islam, THE GUARDIAN (June 4, 2007), available at http://www.guardian.co.uk/politics/2007/jun/04/ immigrationpolicy.religion (describing similar views of Islam from Tony Blair).

4. See, e.g., Teri Judd, For the Women of Iraq, the War is Just Beginning, THE INDEPENDENT (June 8, 2006), available at http://www.independent.co.uk/news/ world/middle-east / for-the-women-of-iraq-the-war-is-just-beginning-481497.html; Maureen Dowd, My Private Idaho, N.Y. TIMES (Aug. 24, 2005), available at http://www.nytimes.com/2005/08/24/opinion/24dowd.html (describing the US as "caving on women's rights" in Iraq).

5. Judd, supra note 4. 
law, whether as the law of the family or otherwise, irrelevant. ${ }^{6}$ Depending on the constituency, this may be phrased as a defense of Saddam himself or merely a salutary aspect of an otherwise bleak period of rule, but the notion that Saddam was a beacon of secularism in a broader Islamist polity is not seriously questioned. All of this changed when Saddam was deposed. Pro-Iranian Islamist parties quickly seized control of the government, and secular rule has generally deteriorated, as the tale is told by our cognoscenti. ${ }^{7}$

In essence, what we learn from this story, in a way a template for the broader misunderstanding of the Muslim world, is that secular law in the region is illegitimate and viewed with suspicion, sustained only by brutal suppression of alternatives. Once alternatives are made available, Islam inserts itself, and a form of classical shari'a, that body of rules and norms derived from sacred text by the medieval jurists of the four schools of thought, becomes the law of the land. A similar story is told, for example, in Turkey, where the ruling party in the Muslim world's most secular state is repeatedly referred to in media outlets as a "moderate Islamist" party. ${ }^{8}$

What then might be able to vindicate some form of secular rule in the Muslim world? This is where our scholars insert themselves where the media leaves off, and provide, as their answer to the conundrum, that same shari'a. If the Constitution, it is argued, declares that laws may not be passed that violate the core tenets, or unambiguous rulings, or certain provisions, of the shari'a, (the socalled repugnancy clauses) then the legislature becomes in essence an administrative authority, enacting secular codes but at the same time in doing so not only avoiding contravening God's rule, but

6. Dowd, supra note 4; Vivian Stromberg, Protecting Women's Rights in Iraq, DET. FREE PRESS (Aug. 10, 2005); Brooke D. Rodgers-Miller, Seminar Papers On Women And Islamic Law: Out Of Jahiliyya: Historic And Modern Incarnations of Polygamy In The Islamic World, 11 WM. \& M. J. WOM. \& L. 541, 561 (2005) (suggesting that the abolishment of the Personal Status Law would reintroduce shari'a); Pamela Constable, Iraqi Women Fear Push For Sharia Law, CHI. TRIB. A2 (Jan. 21, 2004); Charles Clover and Nicolas Pelham, Iraqi Plan for Shari'a Law a 'Sop' to Clerics, Women Say, FIN. TIM. A11 (Jan. 15, 2004).

7. Judd, supra note 4; Dowd, supra note 4, Stromberg, supra note 6; RodgersMiller, supra note 6; Clover and Pelham, supra note 6.

8. See, e.g., Patrick Cockburn, Turks Mull Invasion of Iraq After PKK Ambush, THE INDEPENDENT, October 22, 2007 at 20, available at http://www.independent.co.uk/ news/world/europe/turks-mull-invasion-of-iraq-after-pkk-ambush-397553.html. 
indeed acting in furtherance of the goals of God's Law. As to whether this is good or bad, the learned will differ, but it is the story. The religion, above all, from a legal perspective, is fundamentally about the discovery of God's Law from sacred text, and all else must be justified on the basis of that.

Scholarly books are thus written about Egypt's repugnancy clause, ${ }^{9}$ and tremendous focus is also placed on Iraq's. ${ }^{10}$ Articles appear in respected law reviews decrying this phenomenon as the advent of a pernicious form of "theocratic constitutionalism,"11 or in the alternative describing it hopefully, either as the initiation of rule of law reform in the benighted Abode of Islam ${ }^{12}$ or as a means to balance juristic influence with popular sentiment in the determination of Islamic law.13 Reading elite constitutional scholarship on countries such as Egypt or Iraq, one might be forgiven for thinking that the entire document consisted of a single provision - the repugnancy clause.

From this notion that shari'a justifies the enactment of secular codes through Islamic constitutionalism, much apparently follows in the Western mind, as fruit from a poisonous tree. How to justify the trial and capture of Osama Bin Laden? Try him according to classical Islamic criminal rules! ${ }^{14}$ How about the difficulty of reforming, in Iraq, the means by which security may be obtained for a loan, so that it operates in the manner that our own UCC Article 9 does? Simply create the rules in the manner that comply with Islamic finance! 15

9. Clark B. Lombardi, State Law as islamic LaW in Modern Egypt: The INCORPORATION OF THE SHARI'A INTO EGYPTIAN CONSTITUTIONAL LAW 123 et seq. (2006)

10. See, e.g., Intisar Rabb, "We the Jurists"; Islamic Constitutionalism in Iraq, $10 \mathrm{U}$. PENN. J. CONST. L. 527 (2008); Larry Cata Backer, God(s) Over Constitutions: International and Religious Transnational Constitutionalism in the 21st Century, 27 MISs. C. L. REv. 11 (2007-2008); Noah Feldman, Constitutional Politics and Text in the New Iraq: An Experiment in Islamic Democracy, 75 FORDHAM L. REV. 883 (2006); Ran Hirschl, The Theocratic Challenge to Constitution Drafting in Post-Conflict States, 49 WILLIAM \& MARY L. REV. 1179 (2008).

11. Backer, supra note 10 at 13.

12. NoAh FEldman, THE FAll AND Rise OF THE Islamic STATE 10-13 (2008).

13. Rabb, supra note 10 at 527.

14. Frank E. Vogel, The Trial of Terrorists under Classical Islamic Law, 43 HARv. INTL. L.J. 53 (2002).

15. Mark J. Sundahl, Iraq, Secured Transactions, and the Promise of Islamic Law, 40 VAND. J. TRANS. L. 1301 (2007). 
In the context of Iraq, where much of this discussion is focused, all of this might be interesting, if it sustained even casual interest within Iraq's legal community. I have been making a valiant, though at times unsuccessful, attempt to read through all of the decisions of the Supreme Federal Court of Iraq concerning matters of constitutionality, and I have yet to come upon a case that even cites Article 2 of the Constitution at all. Certainly there have been no reports of any serious engagement with its terms. There is a reason for this - the judges of Baghdad hardly wish to pronounce on shari'a in a manner that might vex the jurists of Najaf, particularly because the Constitution envisages judge and jurist working together on the Court, and no Iraqi judge I have met has the slightest proclivity toward working on a court with people that have no legal training and whose professional culture is entirely different. So long as the court stays out of shari'a, one judge told me, then Najaf will probably stay out of the court.

Whether or not this prognostication is true, we shall see, but on the notion that the Constitution's Article 2 at this point is hardly a matter of great concern to Iraqi lawyers and judges, there can be little doubt. Iraqi legal professionals routinely point to other legal disputes - concerning provincial elections, the fate of Kirkuk, restorations of property expropriated by the former regime, deBa'athification and the like. The mind-numbingly tedious sessions of Parliament, and the refreshingly brief opinions of the Federal Court do not, based on my own studied observations of the same, dwell excessively, if at all, on Article 2 of the Constitution even as they engage any number of other, important legal issues.

While other states, such as Egypt, might well have more developed jurisprudence concerning the repugnancy clause, the attention nevertheless tends to become much ado about relatively little. This is particularly because the Supreme Constitutional Court has taken enormous strides to limit the influence of the repugnancy clause, declaring it, for example, injusticable inasmuch as it concerns claims respecting prior enacted legislation. ${ }^{16}$ This makes the interest provision of the Civil Code valid until the legislature decides to "Islamicize" it. More than two decades have passed, and the

16. Rector of the Azhar University v. President of the Republic, Case No. 20 of Judicial Year No. 1 (Sup. Constitutional Ct.) (Egypt), reprinted in Supreme Constitutional Court (Egypt) - Shari'a and Riba: Decision in Case No. 20 of Judicial Year No. 1, reported in 1 ARAB L. Q. 101 (1985). 
legislature has done nothing of the sort. And so the taking of interest remains as legal today as it has ever been, notwithstanding the repugnancy clause.

This notion that the shari'a must be used to justify the laws of the Muslim world is even more misguided when we leave the world of constitutionalism. No Islamist party in Iraq suggested using Islamic criminal rules to try Saddam Hussein, and the divisions over his trial and execution divide neatly along sectarian lines, not levels of religiosity. In fact, no Iraqi legal professional I know, no matter how devout, no matter how Islamist, would find navigating medieval criminal shari'a any more comprehensible than Attorney General Mukasey would. The notion of Article 9 and Islamic finance seems even more bewildering in a state in which there are no significant Islamic banks, there have been no moves by any major Islamist party to ban the taking of interest on a loan, and the Minister of Finance, from the country's largest Islamist party, has agreed to reductions of state debt in a manner that recognizes a reduced, but very real, obligation to pay down debt, with interest. ${ }^{17}$

In other contexts, much the same conclusions can be drawn. During my last trip to Iraq, this past August, it remained as easy to get a beer in Baghdad as it is in Pennsylvania (which, by the way, is not very easy), and far easier in Suleymania than in New York (meaning the liquor stores were open well into the night, and seven days a week). Unveiled women were still the norm in Suleymania, still the significant minority in Baghdad. Secular law seems as firmly embedded as ever, in this state governed by Islamist parties. Even jurists tend to recognize these central tenets of the postcolonial social and legal order. When they get involved in affairs of the state, and they often do through the issuance of religious rulings or in the context of Friday sermons, they invariably address matters that hardly appear to be Islamic law in any classical sense - the insistence that the constitution be drafted, ${ }^{18}$ or that Parliament pass an Elections Law immediately. ${ }^{19}$ Inasmuch as the jurists address more religious matters (such as the sinful material people are

17. William Neikirk, Debt Deal is a Boon for Iraq, CHI. TRIB. C19 (Dec. 17, 2004).

18. Mohamad Bazzi, The Al-Sistani Factor in Iraq Election, L.A. TIMES, Jan. 30, 2005, available at http://www.latimes.com/news/nationworld/wire/ny-woshia0130,0,5017706.story (relating to Grand Ayatollah Sistani).

19. Islamic Law in Our Times, http://muslimlawprof.org (last visited March 20, 2009). 
watching on television), these rulings and sermons almost invariably do not call for state intervention. ${ }^{20}$ If this is the case in Iraq, it is dramatically the more so in a state like Turkey, where the supposed Islamist party has proclaimed loudly, repeatedly and emphatically that the shari'a has no place in the law of the state.21

None of this is to suggest that Islamic law, of a modern sort, is irrelevant in Muslim polities such as Iraq. In Iraq, Islamist parties have sought to amend the Personal Status Code in a manner that would have some effect on rulemaking in that particular legal field.22 Islamic commerce can be important in private transactions among smaller merchants. ${ }^{23}$ When the state was absent during particularly troublesome times in both Shi'a and Sunni areas, militias took control of areas and enforced their own version of Islamic law. ${ }^{24}$ The fear of nonstate elements being able to do the same now, or in the future, remains acute. ${ }^{25}$

Thus, shari'a is extremely important in non-state capacities, from private commerce to unregistered marriages to private enforcement of dress codes, all of which deserve greater study. It is important in family law. It can at times result in the alteration of particular state rules in the Muslim world (though not Iraq), such as the criminalization of nonmarital sex or the rendering of homosexuality a capital crime, which, if implemented, would have profound effects on the individuals so affected. ${ }^{26}$

20. See id. for English commentary on a Friday sermon by an influential cleric on such matters.

21. AKP Strives to Shrug off Islamist Image, Turkish Daily News, available at http://www.turkishdailynews.com.tr/vote2007/article.php?enewsid=7; Susanna Dokupil, The Separation of Mosque and State: Islam and Democracy in Modern Turkey, 105 W. VA. L. REV. 53, 127 (2002); AKP Official Website, http://eng.akparti.org.tr/ english/partyprogramme.html\#2.1 (last visited Mart 20, 2009) ("Our Party refuses to take advantage of sacred religious values and ethnicity and to use them for political purposes.").

22. Haider Ala Hamoudi, Money Laundering Amidst Mortars: Legislative Process and State Authority in Post-Invasion Iraq, 16 J. TRANSNAT'L. L. \& CONTEM. PROBS. 523, 543 (2007).

23. See generally Haider Ala Hamoudi, Baghdad Booksellers, Basra Carpet Merchants, and the Law of God and Man: Legal Pluralism and the Contemporary Muslim Experience, 1 BERK. J. MIDDLE E. \& ISLAMIC L. 83 (2008).

24. See, e.g., Judd, supra note 4.

25. Steven Farrell, Divining a Lesson in Basra, N.Y. TIMES, Week in Review (May $25,2008)$

26. RuUd Peters, CRIME and Punishment in Islamic LaW 156-58 (2005) (describing Pakistan). 
However, the basic, secular legal foundation on which the state is founded - its training of legal professionals, its secular codes, its rulemaking authorities - are not under threat, not in Egypt, not in Pakistan, not even in Iraq, where Islamists rule. Inasmuch as shari'a plays a role in any Muslim state, it is because it is legitimized through state processes, that is, it is enacted by the state in a manner that complies with Hart's rule of recognition, and is then interpreted by secular lawyers with secular legal training.

That Shi'a jurists and their Shi'a constituencies would, as noted above, prefer shari'a to be developed in a different professional culture, that of the Najaf seminaries, goes a long way to explaining why so little has been enacted by way of Islamic statutes in contemporary Iraq and shari'a's primary force in Iraq lies in nonstate capacities. More Islamization might take place in Sunni countries such as Pakistan or Egypt, where there are weaker juristic influences, but the process is the same. Either the shari'a is a rule of the social order divorced from state law and using entirely private means of enforcement such as shaming and the like, or it is enacted according to secular state processes and applied by secular officials with secular training. The West, then, has the Muslim Rest precisely backwards. Shari'a does not justify secular law, but secular law can recognize and employ shari'a as part of the law. It is the state that grants legitimacy and authority to the shari'a as law, and not the reverse.

Moreover, not only are the notions of state supremacy over law are as firm as ever, but the substantive role of shari'a is also not very much different than it was prior to the invasion. The notion that creeping Islamism was somehow foreign to Saddamist rule is a false one. It was a Saddam era regulation that prevented women from obtaining a passport without the permission of a father or husband.27 Saddam era rules added particularly harsh criminal punishments reminiscent of shari'a such as amputations, though hardly in a manner consistent with shari'a. All of these punishments have now been suspended. The Personal Status Code was always deeply influenced by shari'a, and amendments that made it even more so (unequal rights to inheritance, and a broader right for men to engage in polygamy) were enacted decades before the American

27. Sara Hamoudi, Women's Rights and the Iraqi Constitution in Practice, August 7, 2008, JURIST, available at http://jurist.law.pitt.edu/dateline/ \#2333391928047846327. 
invasion, and years before even Saddam assumed control. ${ }^{28}$ These are often described as secular accommodations to the shari'a to appease Islamist forces. ${ }^{29}$ But in Iraq the Islamists have taken over, and in Pakistan they certainly had a friend in power in the person of General Zia ul Haqq. Yet beyond nonstate applications of shari'a, the only possible changes being discussed (or in the case of Pakistan, enacted) would easily fall within the rubric of similar "accommodations." As we all saw from the dramatic lawyers' demonstrations throughout Pakistan not long ago, the notion that the secular legal system carries no internal legitimacy absent some sort of authority from the shari'a is difficult to support. There is precious little to support the notion that we have been witnessing "the fall and rise of the Islamic state" in the Muslim world.

Unfortunately, however, the West is slow to catch on to these trends. The manifestations of this are evident everywhere. I am asked at academic conferences how it can be that shari'a prohibits the taking of interest, yet Prince Talal invests in Citibank, as if every Muslim is bound first and foremost to the shari'a. A Bahraini female sprinter who wears a headscarf is described in television coverage as a Muslim, her female teammate, dressed more conventionally, yet as Muslim as the first, is not so described. The preferred prerequisite for teaching an increasingly popular course on law school campuses, Islamic law, is not familiarity with contemporary Muslim legal systems, or a foreign law degree from a Muslim state, or even an advanced law degree of any kind, but rather a doctorate in Islamic studies, leaving most able to discuss at length thirteenth century theories on contract, yet less comfortable talking about Sanhuri's Civil Code, the template of Arab private law in the modern world. One might well ask precisely what is so legal about such a course, as far removed as it is from the law of the Muslim polities.

As to what can be done to deal with this rather dispiriting state of affairs, I have no panacea, and even if I did, I do not pretend to have the influence necessary to bring about the realization of my vision. Nevertheless, I can provide, I believe, at least some rudimentary ideas on the manner in which I believe the Muslim East might well be conceived and studied, at least among us

28. Kristen Stilt, Islamic Law and the Making and Remaking of the Iraqi Legal System, 36 GEO. WASH. INT' L. L. REV. 695, 750-54 (2004).

29. Id. at 753; Lombardi, supra note 9. 
comparatists, that would be, at once, less exoticizing, less condescending and less distorting. I provide them in brief below.

First, it seems to me fundamental that if one is to understand law in the Muslim world, the state's legal system must come first, and Islamic law, while important, understood within the context of that system. It is, after all, within the rubric of the state, either in gaps left in the state's legal machinery or in state law enactment, that Islamic law even exists. There are scholars who do this: Mark Cammack has given us excellent work on Islamic law in Indonesia; ${ }^{30}$ Donald Horowitz has written a series of extraordinary articles on the importation of Islamic law into Malaysia in a largely similar manner;31 and Dan Stigall has discussed Islamic law in Iraq to admirable effect. ${ }^{32}$ Unfortunately, however, such material is dwarfed by the amount of work that simply wishes away the state in favor of the construction of medieval rules, many entirely obsolete, in some sort of political, social and economic vacuum. It is not entirely clear by what conception this material can even be considered "law" when so engaged. Certainly it is not any conception of law that lawyers in the Muslim world who I know would be familiar with.

Second, far more work needs to be done on matters concerning the Muslim East that are not directly related to shari'a. I find it quite ironic that in our quest to exoticize the Muslim East, so much focus is placed on the role of Islam, where most comparatists are least equipped to deal, to the derogation of matters in which many would be able to shed more light. How does de-Ba'athification compare to earlier efforts at de-Nazification? What model of property dispute resolution does the Iraq Property Claims Commission employ, and how does it relate to earlier efforts elsewhere in the world to deal with seemingly intractable disputes of this sort? Rather than unnatural and misguided focus on "theocratic constitutionalism," more work might be done as to the extremely broad federalism embodied in the Iraq constitution, as a model for state organization, or how precisely Iraq's extremely generous economic rights might

30. See, e.g., Mark Cammack, Islam, Nationalism and the State in Suharto's Indonesia, 17 WISC. INT. L.J. 27 (1999).

31. Donald Horowitz, The Qur'an And The Common Law: Islamic Law Reform And The Theory Of Legal Change, 42 AM. J. COMP. L. 233 (1994).

32. See generally, e.g., Dan E. Stigall, Iraqi Civil Law: Its Sources, Substance, And Sundering, 16 J. TRANSNAT'L L. \& POL. 1 (2006). 
well be given constitutional meaning. Rather than disquisitions on UCC Article 9 and Islamic finance, analysis of differing local models on obtaining security on a loan might well suggest different means through which polities balance the interests of debtors and various classes of creditors. There appears to me, at first glance, tremendous opportunity to explore issues greatly understudied in the Muslim world, to balance the near exclusive focus on shari'a concerns that are, in many though not all contexts, marginal.

Finally, I think all of our law schools would do well with a few more Muslim lawyers and legal professionals, and a few less experts on medieval jurisprudence. I commend Cornell Law School for offering my friend, Judge Raad Juhi, an opportunity to work there for a year, and have no doubt that the perspective he brings to Iraqi criminal law will be fresh and exciting. As the chief investigative judge during the trial of Saddam Hussein, he will, I am absolutely sure, have comparatively little to say that relates to the shari'a. More interactions of this sort are invaluable, so that law schools, among the Rest, might exchange ideas with their counterparts in the West, and distortions and confusions concerning the true state of law in the Muslim world thereby lessened, at least within our ivory tower. 